\title{
An Experimental Study on the Flame Appearance and Heat Transfer Characteristics of Acoustically Excited Impinging Inverse Diffusion Flames
}

\author{
Ki-Joong Kang ${ }^{1}$ and Kee-Man Lee ${ }^{1^{*}}$ \\ ${ }^{1}$ School of Mechanical and Aerospace Engineering, Sunchon National Univ.$$
\text { 음향 가진된 충돌 역 확산화염의 화염형상과 }
$$$$
\text { 열전달 특성에 관한 실험적 연구 }
$$$$
\text { 강기중 }{ }^{1}, \text { 이기만 }{ }^{*^{*}}
$$ \\ ${ }^{1}$ 순천대학교 기계우주항공공학부
}

\begin{abstract}
An experimental investigation of the flame appearance and heat transfer characteristics in both unexcited and excited impinging inverse diffusion flames with a loud speaker has been performed. The flame is found to become broader and shorter (in length) with acoustic excitation. The heat flux at the stagnation point is increased with the acoustic excitation. The acoustic excitation is more effective in lean conditions than in rich conditions. The reasons for these behaviors are that acoustic excitation improves the entrainment of surrounding air into the jet. From this study, it is found that the maximum increase of $57 \%$ in the total heat flux is obtained at the stagnation point of $\Phi=0.8$. Therefore, it is ascertained that the excitation combustion can be adopted with effective instruments as a method for improving heat transfer in impinging jet flames.
\end{abstract}

요 약 본 오디오 스피커로 음향 가진과 비가진 된 충돌 역 확산화염에서 화염의 형상과 열전달 특성에 관한 실험 적 연구를 수행하였다. 가진에 의해 화염은 반응대가 넓어지고 화염 길이는 좀 더 짧아지는 경향을 보이며 충돌판의 정체점에서 열전달 성능인 열유속은 가진에 의해 향상되는 것으로 나타났다. 이러한 가진 효과는 당량비가 높은 과농 한 상태 보다 상대적으로 낮은 혼합 상태에서 효과적으로 영향을 미치는 것으로 파악되는데 이는 가진에 의해 주위 산화제가 연료 분류로의 유입이 향상되어 나타나는 것으로 판단된다. 이러한 현상으로 본 연구에서는 당량비가 0.8 인 경우 정체점에서 총 열유속이 최대 $57 \%$ 증가되는 것으로 나타났다. 따라서 본 연구를 통해 가진 연소가 충돌 분류 화염에서 열전달 성능을 향상시키는데 효과적인 방법임을 확인하게 되었다.

Key Words : IDF(Inverse diffusion flame), Impinging jet flame, Excited jet flame, Resonant Frequency, Heat flux, Stagnation point

\section{Introduction}

Diffusion flames are desirable for wide flammability and safety. A pre-mixed flame offers the benefit of high temperature and less soot emission. An inverse diffusion flame (IDF) has the advantages of both diffusion flames and pre-mixed flames such as high temperature, safety, and less soot emission. Impinging jets have been widely used in industry for rapidly heating and drying materials. Cheung et al., 2007 examined the effect of the Reynolds number of air $(\mathrm{Re})$, equivalence ratio $(\Phi)$, nozzle-to plate distance $(\mathrm{H} / \mathrm{d})$, and vertical distance from the center of a heat flux sensor using circumferentially arranged fuel ports on the heat-transfer characteristics and flame shape $[1,2]$. Hwang et al., 2003 mentioned the effects of acoustic excitation methods based on the location of the

"Corresponding Author: Kee-Man Lee(kmlee@sucnhon.ac.kr)

Received August 13, $2010 \quad$ Revised (1st August 31, 2010, 2nd September 16, 2010)

Accepted October 15, 2010 
actuator [4]. They found that the flow characteristics of an impinging jet can be changed greatly by control of the vortex pairing and flow development.

Previous studies of excited impinging jets are mostly on non-reacting flow; there are very few studies on reacting flow, especially as a heat-flux improvement method. Therefore, this study seeks to explore the feasibility of acoustic excitation as a method for increasing the heat-transfer ability for impinging heating systems. As a first study, this paper focuses on the mapping of IDFs, and the effect of acoustic excitation on the heat-transfer characteristics and appearance of IDFs. The results obtained from an excited IDF are compared with those of an unexcited IDF.

\section{Experimental set-up}

The burner, heat flux measurement system, and main jet excitation system are shown schematically in Fig. 1. The burner system consists of an inner air nozzle $(4.2 \mathrm{~mm}$ in diameter) and concentric outer fuel nozzle $(7.4 \mathrm{~mm}$ in diameter). Commercial propane is used as the fuel. The heat flux measurement system consists of a water-cooled aluminum plate with a surface area of $255 \mathrm{~mm}^{2}$. The flowrate of the water inlet is controlled to avoid water condensation on the impingement plate. The cooling jacket and impingement plate are attached to a threedimensional positioner so that they can be moved freely. The heat flux from the flame to the plate is measured by a coated heat flux sensor (Vatell Co., TG1000-54T), which is installed at the center of the impingement plate. A data logger is employed to record the heat flux sensor output signal.

Heat-flux measurements are reported every 30 seconds at a rate of 500 samples per second. Before metered air goes into the air tube, combustion air passes through a loudspeaker. To control the jet flow acoustically, the loudspeaker is driven by a function generator; the power amplifier is mounted coaxially beneath the air tube. The frequency is fixed at $148 \mathrm{~Hz}$ as the resonant frequency of the air tube to obtain a large forcing amplitude. The forcing amplitude is defined by the peak-to-peak output voltage of the power amplifier, that is, $V_{P P}$ and is varied from 0 to 50 voltages.

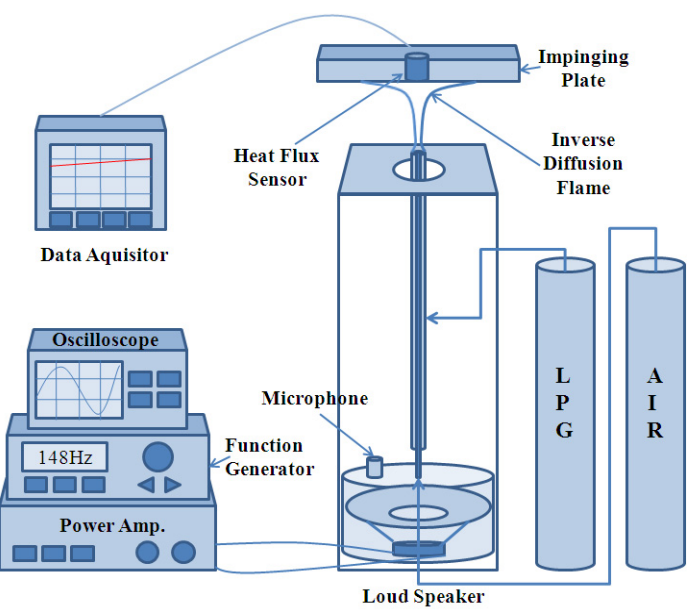

[Fig. 1] Schematic of experimental set-up

\section{Results and discussion}

\subsection{Shape of IDF with and without excitation}

Both unexcited and excited IDFs are classified into four modes and a transient zone (Figs. 3(a) 3(e) and Figs. 4(a) 4(e)) according to shape differences in this investigation. The stability curve of an unexcited IDF is shown in Fig. 2(a). In mode 1, the flame has an air hole inside of the blue flame. In mode 2 , because of the very high velocity of the air jet, fuel is entrained into the air. In mode 3 , the flame is changed into a yellow diffusion flame. In mode 4 , the fuel jet is entrained into a fast enough air jet so that the inner air cone appears. The range of $\operatorname{Re}=3000 \sim 3700$ is the transient zone, and the flame flickers in this mode.

Regarding the excited case, the stability curves of excited IDFs are shown in Fig. 2(b). The flame shapes in modes 2 and 4 do not change much compared to the unexcited case. However, for modes 1 and 3, the flame shapes are different from those in the unexcited case. In the case of mode 1 , the blue flame rolls up like a mushroom because of the excitation. In mode 3 , the flame changes into a yellow flame and the lower part of the flame is ridged. In comparison with the unexcited case, the transient zone is wider in the excited case. The range of stability narrowed as the forcing amplitude increased. 


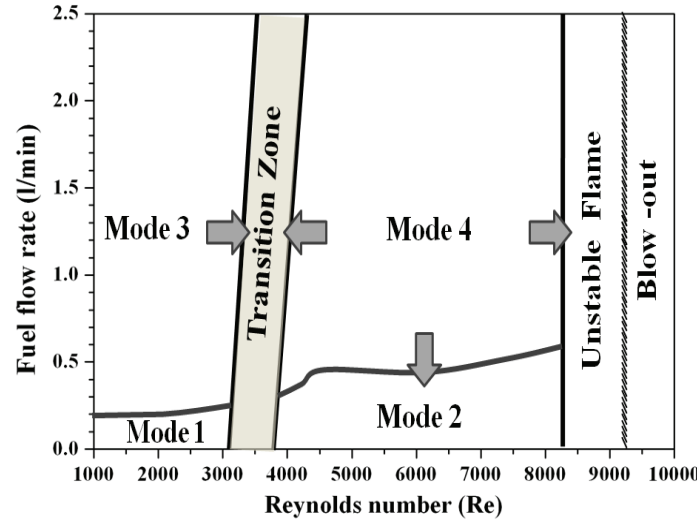

(a) Unexcited stability

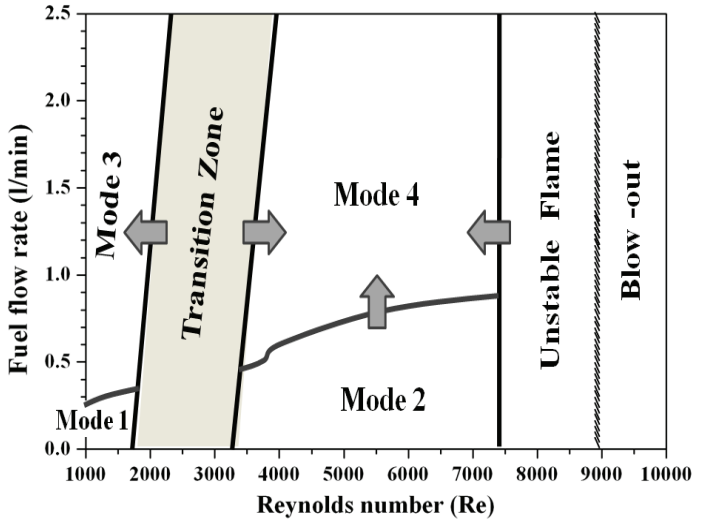

(b) Excited stability (50Voltage)

[Fig. 2] Stability curves of unexcited and excited IDFs

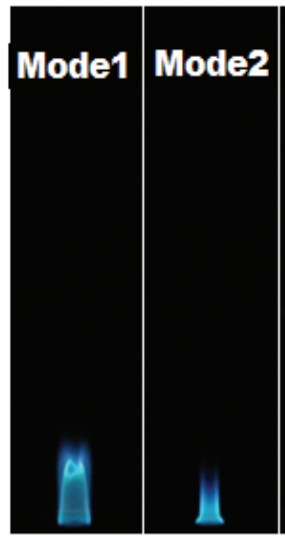

(a) (b)

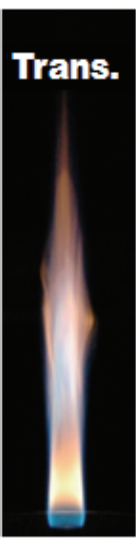

(c)

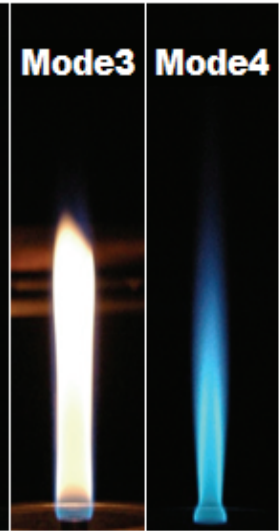

(d)

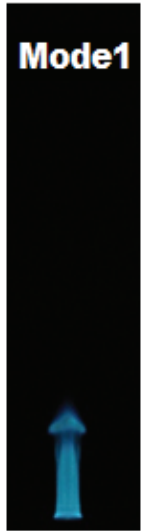

(a)

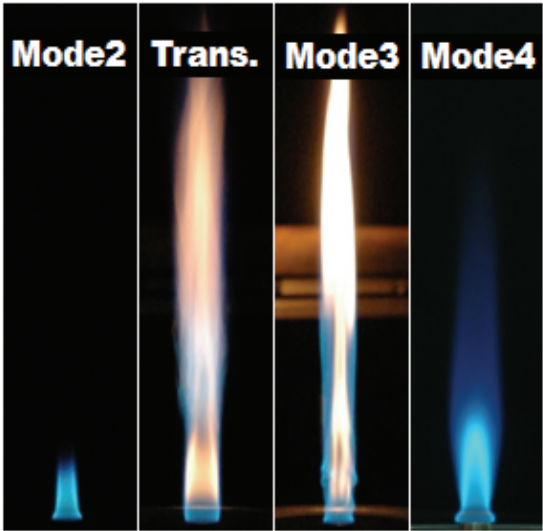

(c) (d)

[Fig. 3] Four modes and transient flame of unexcited IDFs

\subsection{Heat flux distribution of unexcited IDFs}

\subsubsection{Heat flux at the stagnation point}

(1) Effect of Reynolds number(Re) and equivalence $\operatorname{ratio}(\Phi)$

The effects of the Reynolds number (Re) and equivalence ratio $(\Phi)$ on the stagnation point are shown in Fig. 5. For every Re, the heat flux increases to a sudden point and then decreases with an increase in $\Phi$. For most values of Re, the peak values of the heat flux occur around $\Phi=1.4$. For $\mathrm{Re}=6000$, the peak value of the heat flux is lower than at $\mathrm{Re}=5000$.

These results can be explained in the following

[Fig. 4] Four modes and transient flame of excited IDFs manner. In the range of the Reynolds number of $3000 \sim 5000$, the higher velocity of air should aid the mixing of air and fuel. However, at $\mathrm{Re}=6000$, the air velocity is too high; therefore, a cold air jet hits the impingement plate, which lowers the peak value of the heat flux.

(2) Effect of dimensionless height(H/d)

When the Reynolds number is fixed with 5000, the variations of stagnation point heat flux are show in Fig. 6. The lines in the Figure represent the variation in heat flux at different $\Phi$ raging from 0.4 to 1.8 according to the vertical position, that is, $\mathrm{H} / \mathrm{d}$. For $\mathrm{H} / \mathrm{d}>18$, the heat flux is became stable as constant values. The result can be 
explained as follows. The range of $\mathrm{H} / \mathrm{d}<10$, a cold air jet hit the impingement plate directly, resulting in very low heat flux. The increase in $\Phi$ is associated with an increase in the length required for mixing and combustion.

\subsubsection{Radial heat flux distribution}

(1) Effect of Reynolds number

The effect of the Reynolds number is shown in Fig. 7. Here, both $\Phi$ and $\mathrm{H} / \mathrm{d}$ are fixed at 1.4 and 15, respectively. The heat flux generally increases as the Reynolds number increases. At $\mathrm{Re}=6000$, the peak value of the heat flux is shifted slightly because of the impact of the high velocity of the air jet.

The effect of $\Phi$ on the radial heat flux distribution is shown in Fig. 8. From $\Phi=0.6$ to 1.0 , the peak value of

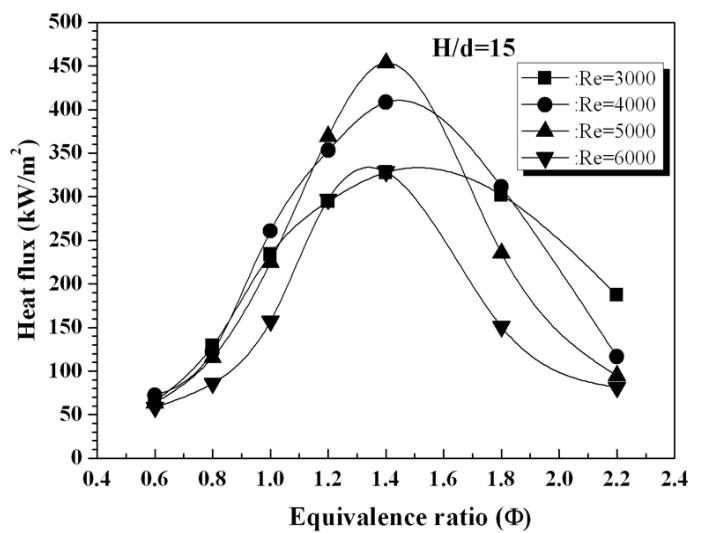

[Fig. 5] Variation of stagnation point heat flux with $\Phi$ and $\operatorname{Re}$ at $\mathrm{H} / \mathrm{d}=15$

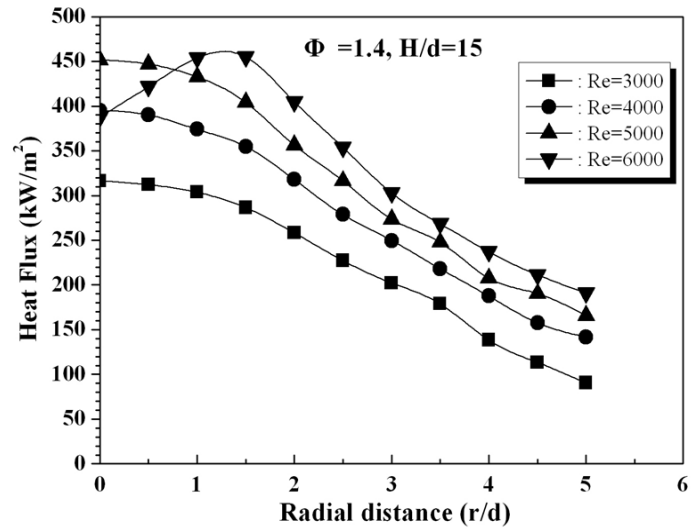

[Fig. 7] Effect of Re on radial heat flux distribution with $\mathrm{H} / \mathrm{d}=15, \Phi=1.4$ the heat flux is shifted from the stagnation point because of the entrainment of much ambient air. When $\Phi$ is 1.8 (a rich condition), the heat flux decreases because of incomplete combustion.

\section{(2) Effect of $\mathrm{H} / \mathrm{d}$}

For various nozzle-to-plate distances, the radial heat flux distribution is shown in Fig. 9. For $\mathrm{H} / \mathrm{d}=10$ and 15, the heat flux increases with the radial length (r/d) until a peak value is reached; then, it decreases steadily as the radial length $(\mathrm{r} / \mathrm{d})$ increases. A smaller heat flux at the stagnation point indicates that there is a cold air jet in the flame that hits the impingement plate at a small nozzle-to-plate distance. For $\mathrm{H} / \mathrm{d}=20$ or more, the peak value of the heat flux occurs at the stagnation point and the heat flux decreases as the radial length increases.

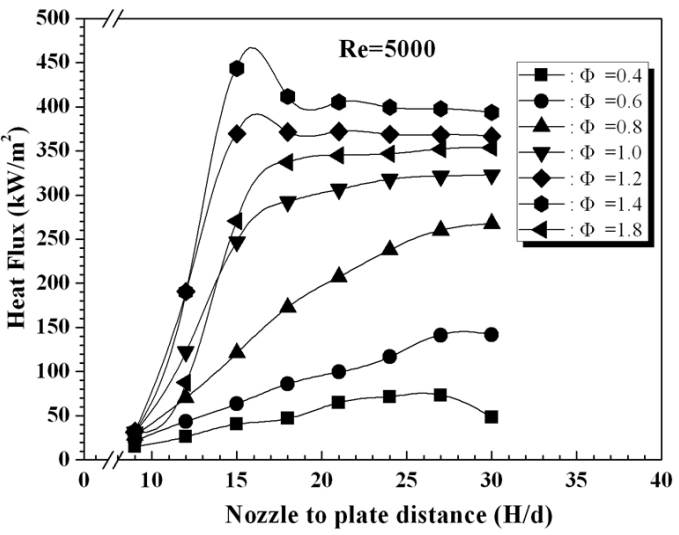

[Fig. 6] Variation of stagnation point heat flux with $\mathrm{H} / \mathrm{d}$ and $\Phi$ at $\mathrm{Re}=5000$

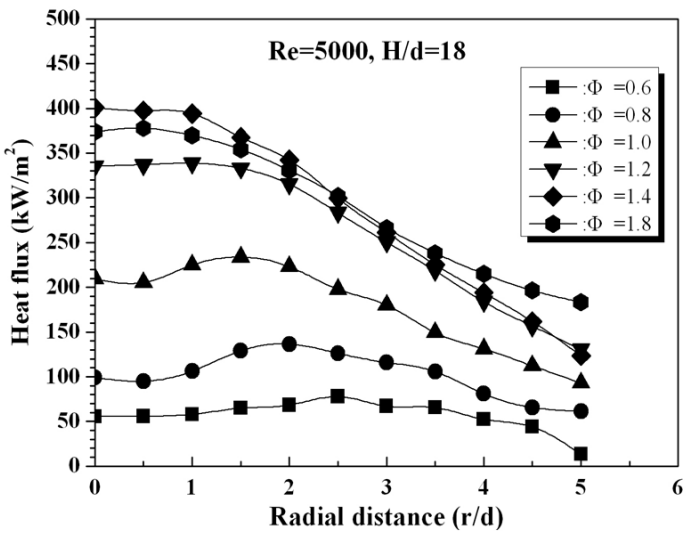

[Fig. 8] Effect of $\Phi$ on radial heat flux distribution with $\mathrm{Re}=5000, \mathrm{H} / \mathrm{d}=18$ 


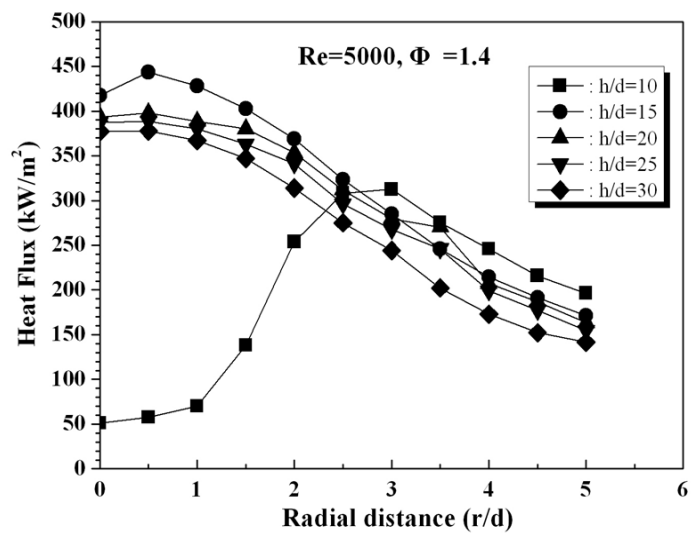

[Fig. 9] Effect of $\mathrm{H} / \mathrm{d}$ on radial heat flux distribution with $\mathrm{Re}=5000, \Phi=1.4$

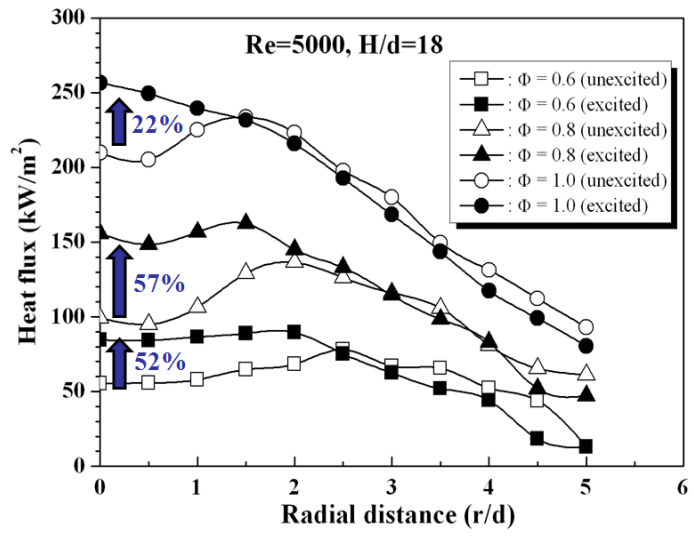

(a) Lean condition $(\Phi=0.6 \sim 1.0)$

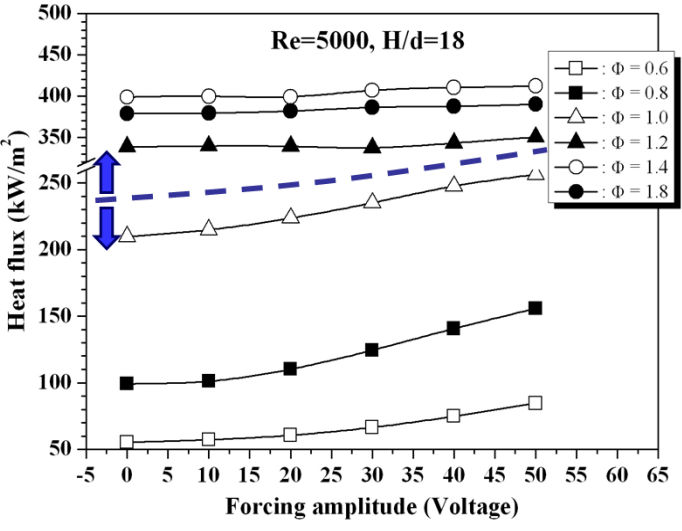

[Fig. 10] Effect of excitation and $\Phi$ on heat flux at the stagnation point

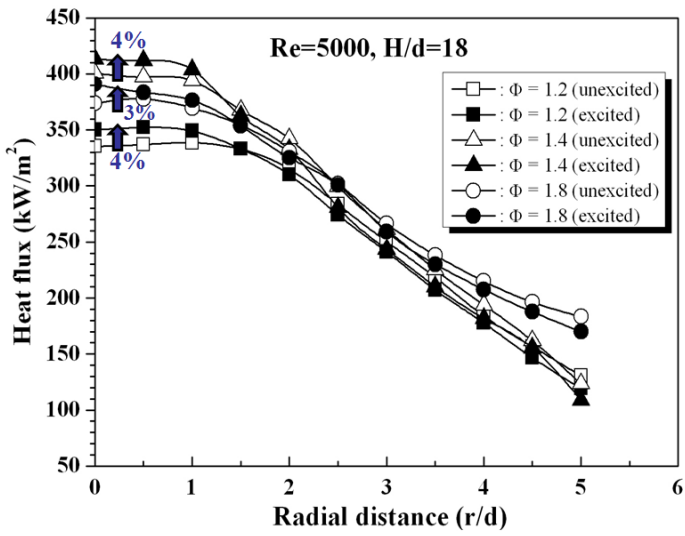

(b) Rich condition $(\Phi=1.2 \sim 1.8)$

[Fig. 11] Effect of excitation on radial heat flux distribution at $\mathrm{Re}=5000, \mathrm{H} / \mathrm{d}=18$

[Table 1] Enhancement of heat flux with excitation $(50 \mathrm{~V}, \mathrm{Re}=5000, \mathrm{H} / \mathrm{d}=18)$

\begin{tabular}{|c|c|c|c|}
\hline$\Phi$ & Heat flux of unexcited flame $\left(\mathrm{kW} / \mathrm{m}^{2}\right)$ & Heat flux of excited flame $\left(\mathrm{kW} / \mathrm{m}^{2}\right)$ & Enhancement rates $(\%)$ \\
\hline 0.6 & 55 & 84 & 52 \\
\hline 0.8 & 99 & 155 & 57 \\
\hline 1.0 & 209 & 256 & 22 \\
\hline 1.2 & 335 & 350 & 4 \\
\hline 1.4 & 400 & 413 & 3 \\
\hline 1.8 & 374 & 390 & 4 \\
\hline
\end{tabular}

\subsection{Heat flux distribution of excited IDF}

\subsubsection{Heat flux at the stagnation point}

The heat-transfer characteristics of unexcited and excited IDFs are shown in Fig. 10. The heat flux at the stagnation point increases with an increase in the forcing amplitude. The increase in the heat flux for each equivalence ratio is shown in Table 1 . In the range of $\Phi$ $=0.6 \sim 1.0$ (lean condition), excitation is more effective and in the range of $\Phi=1.2 \sim 1.8$ (rich condition), the excitation effect is much smaller. Therefore, it is known that as the 
equivalence ratio increases, the excitation effect decreases. The biggest increase in the heat flux occurs at $\Phi=0.8$ $(57 \%)$. The result can be explained as follows. In the range of $\Phi=0.6 \sim 1.0$, the fuel jet velocity is low enough for the fuel jet to mix well with the air jet through excitation. However, in the range of $\Phi=1.2 \sim 1.8$, the velocity of the fuel jet is too high at the same level of acoustic excitation so that the effect of excitation is smaller

\subsubsection{Radial heat flux distribution}

For various equivalence ratios, the radial heat flux distribution of an excited flame is shown in Figs. 11(a) 11(b). These figures show that the heat flux at the stagnation point is enhanced by acoustic excitation. However, as the radial length $(\mathrm{r} / \mathrm{d})$ increases, the heat flux of the excited flame decreases sharply compared to the heat flux of the unexcited flame. This can be explained as follows. Because of a high level of turbulence intensity, the excited flame is shorter than an unexcited flame.

\section{Conclusions}

In this study, the flame appearance and heat flux distribution of both unexcited and acoustic excited IDFs are investigated. For unexcited and excited IDFs under a range of forcing amplitudes at a fixed resonant frequency, the following conclusions are obtained.

1) There are four modes for both unexcited and excited IDFs and a transient zone according to the shape difference depending on the flow rates of air and fuel.

2) The heat flux of the stagnation point is affected by Re, $\Phi$, and the nozzle-to- impingement-plate distance. The nozzle-to- impingement-plate distance greatly affects the radial heat flux distribution, because of the existence of a cold inner air jet. An increase in the Reynolds number generally will increase the heat flux. The peak value is founded at a richer condition $(\Phi=1.4)$.

3) Excited IDFs have higher heat fluxes at the stagnation point. However, regarding the radial heat flux distribution, the heat flux of excited IDFs decreases sharply compared to the heat flux of unexcited flames as the radial length $(\mathrm{r} / \mathrm{d})$ increases. The reason for this behavior is that the flame becomes shorter with acoustic excitation.

4) Acoustic excitation significantly enhances the heat flux at the stagnation point in lean conditions $(\Phi$ $=0.8 \sim 1.0$ ). Especially, an increase in the total heat flux of $57 \%$ is obtained at $\Phi=0.8$. However, this is not much affected in rich conditions. The reason for this result is that the velocity of the fuel jet is too high for the fuel jet to be mixed with the air jet at the same level of acoustic excitation in rich conditions $(\Phi=1.2 \sim 1.8)$.

Nevertheless, it is ascertained that excitation combustion could be adopted with an effective instrument as a heat-transfer improvement method for impinging jet flames.

\section{Acknowledgment}

This work was supported by Basic Science Research Program through the National Research Foundation of Korea funded by the Ministry of Education, Science and Technology. (NRF-2010-0016857)

\section{References}

[1] C.S Cheung, C.W. Leung and L.L. Dong, "Heat transfer characteristics of an impinging inverse diffusion flame jet-part 1:free flame structure", International journal of heat and mass transfer, Vol. 50, pp. 5108-5123, 2007.

[2] C.S Cheung, C.W. Leung and L.L. Dong, "Heat transfer characteristics of an impinging inverse diffusion flame jet-part 2:impinging flame structure and impingement heat transfer", International journal of heat and mass transfer, Vol. 50, pp. 5124-5138, 2007.

[3] Tianshu Liu and J.P. Sullivan, "Heat Transfer and Flow Structures in an Excited Circular Impinging Jet", Int. J. Heat and Mass Transfer, Vol. 39, No. 17, pp. 3695-3706, 1996.

[4] S.D. Hwang and H.H. Cho, "Effects of Acoustic Excitation Positions on Heat Transfer and Flow in Axisymmetric Impinging Jet : Main Jet Excitation and Shear Layer Excitation", Int. J. of Heat and Mass Fluid 
Flow, Vol. 24, pp. 199-209, 2003.

[5] P.A. Eibeck, J.O. Keller, T.T. Bramlette and D.J. Sailor, "Pulse Combustion: Impinging Jet Heat Transfer Enhancement", Combustion Science and Technology, Vol. 94, pp. 147-165, 1993.

[6] H. M. Hofmann, D.L. Movileanu, M. Kind and H. Martin, "Influence of a Pulsation on Heat Transfer and Flow Structure in Submerged Impinging Jets", Int. J. Heat and Mass Transfer, Vol. 50, pp. 3638-3648, 2007.

[7] Kee-Man Lee, "A Visual Study on the turnabout Phenomenon of Vortex Roll-up in forced Jet Diffusion Flames", Journal of Mechanical Science and Technology, Vol. 21, pp. 2221-2228, 2007.

[8] C.H. Hwang, K.M. Lee and S.M. Kum, "NOx Formation Characteristics on Heat Loss Rate for CH4/Air Premixed Flames in a Perfectly Stirred Reactor", Journal of the Korea Academia Industrial Cooperation Society, Vol. 7, pp. 1465-1472, 2009.

\section{Kee-Man Lee}

[Regular member]

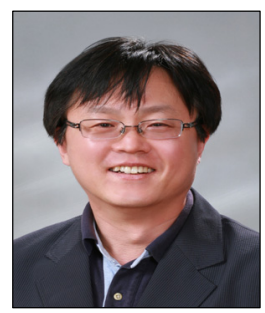

- Feb. 1983 : Inha Univ., B.S

- Feb. 1998 : KAIST., Ph.D

- Feb. $1998 \sim$ March 2007 : Provincial College of Damyang, Dept. of Mech. Engineering

- March $2007 \sim$ Present : Sunchon Nat. Univ. School of Mechanical and Aerospace Engineering

$<$ Research Interests $>$

Combustion, Propulsion, Heat Transfer

\section{Ki-Joong Kang}

[Regular member]

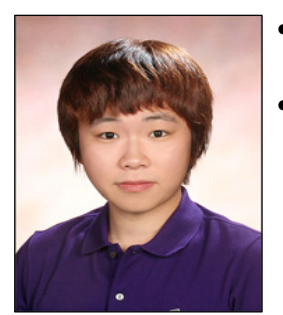

- Feb. 2010 : Sunchon Nat. Univ., B.S

- Feb. $2010 \sim$ Present : Graduate School of Sunchon Nat. Univ., Master Course

$<$ Research Interests $>$

Combustion, Heat transfer 